\title{
COMMUNICATION
}

\section{HUGO SINZHEIMER-THE FATHER OF GERMAN LABOUR LAW}

April 12, 1975 would be Professor Sinzheimer's hundredth birthday. The first point of contact of the Israel lawyer with his work is the collective labour agreement. For by speaking as a matter of course of its "normative function" we adopt a term coined by him, and even more, an insight into the nature of a modern legal institute won by him before the first World War. Contracts in favour of third parties had been known in Germany since the Middle Ages and their force and nature had been explored and explained; but here also duties were imposed on employers and workers who, though members of the parties to the agreement, were not themselves parties to it, and such duties were actually complied with and (in Germany since 1910) enforced. In his two volume book, Der korporative Arbeitsnormenvertrag (1907-8) (The Collective Labour Agreement) Sinzheimer was the first to enquire into the structure of these agreements. Later, in his work Ein Arbeitstarifgesetz-die Idee der sozialen Selbstbestimmung im Recht (1916) (A Collective Labour Agreement-The Idea of Social Self-Determination in Law) containing a complete bill of 109 sections, which was never enacted but served as a basis for subsequent legislation, he was the first to draft a law regulating conditions of their conclusion and validity. Today his teaching on the nature of collective labour agreements is accepted even in countries where the general law of contract is based on different principles than in Germany.

In the collective labour agreement (as in other objects of his research) Sinzheimer sought not only a solution to an intriguing new legal problem, but above all, an answer to burning social needs. He was sensitive to the contrast between the monolithic, impersonal State, and corporations of a more personal character, such as trade unions, where members found room for active participation-a contrast not dissimilar to that between the English Mandatory Government of Palestine and the Va'ad Le'umi or the Histadruth with their more progressive self-government activities. Moreover, deriving, as he did, such deep satisfaction from his work as a free advocate, he was disturbed by the mental separation of the manual worker from his trade, from society as it then existed, and from the State. As long as collective agreements were not put on a firm legal basis, the worker could 
not even effectively bargain on his own conditions of work. Sinzheimer did not invent or discover the collective labour agreement (for its discovery he gave credit to his teacher Philipp Lotmar), but he made it an effective legal instrument.

While collective bargaining was chiefly done by trade unions comprising whole industries or trades, there also existed, here and there even in pre1914 Germany, works councils representing only those employed at one place or by one employer; but before the war they were neither numerous nor influential. Only after about 1916 did their importance increase, and with the impetus of the German revolution (1918) they turned their attention from internal, social aims to political ones: influence on the management of works, directing the country's economy, even dominating the State-the very objects gained the year before by the Russian Soviets ("councils"). From the end of 1918 till 1921-22 Germany was seething with revolution, terror, military action and political murder. Sinzheimer, elected to the Constituent Assembly (1919), became aware of both the danger of sovietization of the new Republic and the genuine popular forces within the movement for extending the influence of the workers' councils. In a report to the Constitution Committee of the Assembly he wrote: "One. . . has to admit that in the councils movement a strong current of idealism finds expression, an infinite yearning to escape the terrible conditions in which the people are living, some idea of salvation". (Quoted from E. Fraenkel, "Rätemythos und soziale Selbstbestimmung" (Workers Councils Myth and Social Self-Determination) in: Das Parlament, 3.7.1971, B 14, p. 23). If the workers were not content with being mere cogs in the machinery, their demand conformed with Sinzheimer's own notions. The problem was, how to realize their claim without upsetting the democratic structure of the State. With this aim in view he drafted the then famous art. 165 of the Weimar Constitution (not repeated in the Basic Law of the present Federal Republic of Germany). Art. 165 provided, side by side with the political institutions of the State, for a double system of social and economic representation: on the one hand pure workers' councils on three levels (plant, region and State), and on the other, mixed representation, on the regional and State level, so-called "economic councils" in which the corresponding workers' councils were to be balanced by representatives of the employers and of other factors concerned. These councils were to act as consultative bodies, but might also be given administrative and supervisory powers.

Sinzheimer's art. 165 was conceived as a constructive compromise between the demand for an early realization of the doctrine of the dictatorship of the proletariate (through its workers' councils) and the attempt to set up a socially progressive, though politically conservative democracy. It shows the wide range of Sinzheimer's vision and his fertile power of imagination. But it was never given a chance to function: apart from the works councils at the plant level, which were regulated by a law of 1920, most of the bodies 
envisaged in art. 165 were never set up. For an appreciation of Sinzheimer's work and concepts it is nevertheless of undiminished importance; it is another expression of his social, humane approach to a burning question of the time, no less than his studies, writings and recommendations concerning the collective agreement.

In 1920 Sinzheimer retired from politics, concentrating on his double profession as legal counsel (he was a successful criminal lawyer and also legai adviser to the General Trade Unions) and as teacher of labour law. He has been called the father of German labour law. Much of his work is bound up with special features of German law and legal science which are too remote from the Israel reader's way of thinking to be explained in a memorial note. Among other writings he published a short textbook Grundzuege des Arbeitsrechts (Principles of Labour Law) whose concise formulations gave his pupils a useful introduction to labour law. To listen to his lectures was sheer delight. Tall, broadly built, of strong Jewish features, he was an impressive figure, a master of the spoken word and of the accompanying gesture. His art and his intellectual charm stood him well, not only in the lecture room, but in court, in Parliament and in public assemblies. But his eloquence was more than a happy gift-what he had to say was the result of broad, serious study, of long deliberation and of ten of lively debate in the circle of his disciples. It was a privilege to attend his preparation of cases or of his expert opinions on some new question of labour law. In the twenties and early thirties the emergence of new questions in this field was an almost daily occurrence. He sparkled with ideas. It might happen that his bright pupils, more interested in formal logic, found fault with his methods of deduction: he would then immediately modify his approach, throw another idea into the debate, weave an entire net of new connections, until the final, polished solution emerged.

In 1933, not unexpected by him, that happy world collapsed. Well-known and hated as a Jew and as an adherent to the republican régime, Sinzheimer was dragged through the streets of Frankfurt. But he retained his warm humanity; he remained accessible to his old pupils, ready to provide them with letters of introduction for resettlement abroad, both before he left Germany himself, and even after he had found a new place to live and work. The universities of Amsterdam and Leyden provided him with a new chair, to lecture on the Sociology of Law, and for another seven years he was able to teach and write in apparent safety.

The subject of his inaugural address in Amsterdam was the theme of his life-work: Das Problem des Menschen im Recht (The Problem of Man in the Law). Best known among his publications from this period is his book Jüdische Klassiker der deutschen Rechtswissenschaft (Jewish Classicists of German Legal Science), twelve comprehensive sketches of Jewish lawyers and their contribution to the science of law in Germany. The specialties of these masters (who were all academic teachers, though some acted also as judges 
or as legal draftsmen) comprised Roman and medieval German law, legal philosophy, commercial, labour, criminal law and their reform, constitutional law-an enormous field of learning, reflecting the wide range of Sinzheimer's own interest and study. The object of this book was to refute the national-socialist thesis of the destructive influence of the Jewish spirit on German legal science. It denied the existence of anything specifically Jewish in the scientific work of those Jewish classicists: "The spirit of the Jewish classicists of German legal science is simply scientific spirit": this proposition summarizes the essence of the book. When we ask what was Jewish in these Jewish masters, it is, in the main, their descent, sometimes their religion, but not their work. Some of them proudly asserted their Jewishness, such as Levin Goldschmidt in that moving letter (quoted in full) in which he severed his ties of friendship with Treitschke after the latter turned to anti-semitism. But the mere idea of a specific Jewish contribution to German science was, in the context of the book, unthinkable. Were there indeed no exceptions, no Jewish elements in the work of Jewish scholars? A few of them, we presume, may have made some specific contribution to legal discussions going on in Germany. One of them was Zacharias Frankel, a Rabbi well versed in secular law, whose works on the Jewish law of evidence $(1840,1846)$ may be counted among the most original contributions to the vast literature on the use and misuse of the oath in German civil and criminal procedure. But on the whole Sinzheimer was tragically right: in order to participate in the development of legal science in Germany, a Jew had to repress all that was typically Jewish in him. He might be a good Jew, might be active in Jewish affairs (few of those chosen for Sinzheimer's collection were either), but his Jewishness could not show in his work.

In 1940 the Germans invaded Holland. Sinzheimer had to go into hiding. It is hard to imagine what such imprisonment, although "voluntary", must have meant for a man so accustomed to, so much in need of, movement, communication, freedom. Nevertheless he was able to work and even to write a new book: Theorie der Gesetzgebung: Die Idee der Evolution im Recht (Theory of Legislation: The Idea of Evolution in the Law). He survived the war, but died soon after it came to an end, a septuagenarian, on September 19, 1945.

Sinzheimer's pupils are today dispersed throughout the world. Some of them continue his life-work in various fields of law and legal science; many will forever remember with gratitude his teaching, his personal influence and his rich and charming personality.

Ernst Livneh*

* Dr. Jur., Research Fellow, Sacher Institute of Legislative Research and Comparative Law, Hebrew University of Jerusalem. 